\title{
POLITICAL LEADERSHIP OF MUHAMMAD ALI JINNAH: HIS TASK MANAGEMENT TACTICS AND GOAL ORIENTATION STRATEGIES
}

\author{
Ghulam Shabbir \\ Lecturer, Department of History \& Pakistan Studies \\ University of Gujrat, Gujrat, Pakistan. \\ ghulam.shabbir@uog.edu.pk \\ Khizar Jawad \\ Assistant Professor, Department of History \\ FC College University, Lahore, Pakistan. \\ khizarjawad@fccollege.edu.pk \\ Azmat Ullah \\ Assistant Professor, Department of History \\ Government College University, Faisalabad, Pakistan \\ azmat.wzr@gmail.com
}

\begin{abstract}
Like most charismatic leaders Jinnah was an exceptionally gifted discrete who had the competency to pass out of his nation from solitude. It was his collective understanding of the obligation and the prominence of contribution to his nation. After the self-exile in England, his re-entry into the Indian politics strengthened the strategy of his future's politics. The instantaneous difficulty for him was how to formulate a stratagem that could form the conditional dynamism in such a way that it generates opportunities for the Muslims to understand their determinations. This study has analysed his task management tactics and goal orientation strategies during the Freedom Movement. This is archival based research, and the argument is developed through the historical, descriptive, and analytical methods.
\end{abstract}

Key Words: Jinnah, Gandhi, Nehru, Congress Ministries, Quit India Movement, Jinnah-Gandhi Talks, Cabinet Mission Plan

\section{INTRODUCTION}

Jinnah in this perspective a comprehensive pattern of strategy established on four major elements to achieve his goal orientation. The first task was to reorganize Muslim League and recognized it as all India level political party. After attaining this objective, he moved towards the second objective to promote the idea of a separate homeland among his fellow Muslims. After this, being a charismatic leader to accomplish the reputation of the sole spokesman of the Muslims. At the final stage, he will bargain with the British and Congress on equal footing to achieve his prime goal. After attaining these goals, he established a nation-state based on Islamic principles and it would become merely a product of situational demand.

\section{JINNAH AND HIS STRATEGY TO REORGANIZE THE MUSLIMS}

Mr. Jinnah believed that the reorganization of the Muslim and Muslim league would be proved as a turning point in the political amphitheatre of India. He addressed Muslim League members; we would prefer the interests of the Muslim nation. This is the only solution to recognize our manifestation to our opponents. Now the paramount challenge is that to consolidate yourself for a greater cause (Bolitho, 2006). In October 1937, on the annual session of the Muslim League, held at Lucknow, he reinvigorated the Muslims that until we should not reorganize the Muslim League the demand of a separate Muslim homeland could not be accomplished. Further, he added in his same speech, there was only one lesson for the Muslims that Muslims should learn, to play your vigorous role in this movement. He believed that the time had come to reorganize for a greater cause and develop our power without any other consideration (Ahmad, 1968). 
Now alongside with this task, he adopted a new tactic to expose Congress as a pro-Hindu organization and it had no sympathies for the Muslims. After that Jinnah decided to deliver fiery discourses against Congress and conveyed that they want to establish a Hindu-Raj in India. This was the Jinnah's and his party policy to expose the anti-Muslim policies of Congress.

\section{JINNAH'S POLITICAL TACTICS AND THE CONGRESS}

Jinnah declared, while he was addressing a Muslim gathering on 13 October 1938, the sole agenda of the Congress revolve around this logic to overwhelm the Muslims in India (Casci, 1998). From $26^{\text {th }}$ to $29^{\text {th }}$ December 1938, the annual session of the Muslim League was held at Patna. During this session, Jinnah summarised, the Congress High Command was determined to crush the other native communities in India, and they had only an agenda to bring back the Hindu authoritarianism. He criticised the slogan of Swaraj and he assimilated it with the Hindu Raj. Further, he added, their mandate of self-government destined the Hindu government only (Ahmad, 1968).

Jinnah smeared the Congress and its policies that were causing communal violence in India. $\mathrm{He}$ and his party believed in communal peace in the country (Casci, 1998). To strengthen this objective, the Muslim League organised and circulated many formal reports to highlight the injustice of Congress with other communities during their Provincial Ministries. In this case, two famous reports came into the front, the Sharif Report and the Pirpur Report(Hayat, 2008). These two reports played an influential role to mould the Muslim's mindset towards Muslim League and somehow these reports exaggerated the situation.

This propaganda mechanism had suffered for multiple purposes. Firstly, this move got rid of an accusation on him that he was too friendly with Congress. His Muslim counterparts alleged that his secular ideology had a soft corner for Congress. He decided to embrace a skilful meditation which based on his resilient determination to accomplish his goal (Sayeed, 1968).

Secondly, this move clearly brought a fear of Hindu Raj among the minds of Muslims. No doubt, this tactic was effective, and a large community of Muslims decided to join the Muslim League. This occurred after the rejection of Congress to form the collation government with the Muslim League. Under Sardar Patel's direction, the Congress announced that if Muslim Leaguers were willing to form a collation then they must merge their party within the Congress (Stephan, 1976). This move known as the Himalayan blunder of Congress which strengthened the position of Jinnah and he easily became able to convince the Muslims against the attitude of Congress (Bilgrami, 1985). During a speech at Lucknow, he presaged the Muslims about the intentions of the majority community in India. He claimed that these policies of the Congress would increase the class animosity and communal viciousness in India (Bolitho, 2006). This approach of the Congress to neglect and side-lined the Muslim League confirmed the trepidations of the Muslim community in India (Biswas, 2021).

These were the prime factors behind the success of Jinnah's call for 'Day of Deliverance' on 22 December 1939 (Moore, 1983), attracted a large number of demonstrators, including, Muslims, Parsees, Christian and Untouchables. His strategy became successful, but till 1940, the preoccupation of Jinnah on the political horizon of India became more strengthened as he propagated the position of the Muslim League as a third political force in India (Hobson, 2002). Jinnah was continuously convincing his followers through these tactics that they had to seek a haven in a strong unity. Another outstanding aspect of Jinnah's leadership was that he scrupulously refrained from showing his main objectives in his speeches and statements. Furthermore, Jinnah constantly used a phrase to portrait the fear of Hindu authoritarianism among his followers. Many prominent historians argued that he wanted to use them as a bargaining chip at right time. This strategy could only be successful after having the Muslim League the sole representative organization of the Muslims.

The political blunders of Congress had paved the way for Jinnah to successfully execute the first stage of his strategy. In the early 1940s, Jinnah promoted this idea the British democracy had limitations in India and its use in such a heterogeneous country was inapplicable. On 19 January 1940, Time and Tide (Camboni, 2004) published an article by Jinnah under the caption, 'The Constitutional Future of India' (S.M. Burke, 2009) in this piece of writing he suggested the British to recognize the two-nation theory in India. After a few days in Lahore Resolution, 1940, he pronounced the idea of a separate state for the Muslims (Bilgrami, 1985). Finally, the Indian Muslims had to descent the impression of one nation and they decided to attain their separate homeland (Stephan, 1976). In an 
answer about details of the Pakistan plan, Jinnah said that the situational factor had become so resilient and the mandate of a separate state for the Muslims couldn't be denied (Nichols, 1944).

\section{POLITICAL STRATEGIES OF JINNAH AND FINAL GOAL ORIENTATION}

After the Lahore Resolution the demand of Pakistan was still blurred and hazy (Khaliq-uz-Zaman, 1961). Jinnah was taking full advantage of the situation and wanted to bring Congress to the table. It was a fact that the League workers had to require a huge effort to convince the Indian Muslims for the demand of Pakistan. On this occasion Congress again committed a blunder, their over-enthusiastic efforts to discredit Pakistan, this move again went in the favour of the Muslim League and the proCongress press professed Lahore Resolution as Pakistan Resolution was another miscalculation (Casci, 1998).

Attaining abrupt success in his previous strategies, Jinnah started the fourth stage of his strategy which was the independence for his fellow Muslims. The Second World War was started and the British declared war against Hitler on $3^{\text {rd }}$ September 1939, and the same day Viceroy announced India was at war with Nazis without consulting the Indian leadership (Blanchot, 2012). Now the British Government was eager to gain assistance from Indian political parties, especially, Congress. The attitude of the Congress was totally against the British for having deliberately ignored and asked for immediate independent status. Jinnah waited until Congress had made its announcement. Jinnah expressed his willingness to support the British government in war (Corder \& Plaut, 2014). Jinnah as a great strategist claimed justice and fair play against the atrocity of the Congress rule in Muslim areas. He demanded that no constitution or declaration would be implemented in India without the consent and approval of the Muslim League (Hodson, 1969). It was the tactics of Jinnah that the Viceroy had to announce in October 1939, the rights of minorities such as the Muslims would be safeguarded in the forthcoming constitution (Wallbank, 1958).

At this critical juncture of history, Congress again left the political stage of India empty for Jinnah. Congress decided to non-cooperation with the British during the war. Jinnah had realized the difficult situation the British were confronting and he restrained cooperation with the British (Jalal, 1998). This move of Jinnah brought fruit in Viceroy's August Offers (Jalal, 2010), when he assured the full weight would be provided to the minorities in constitutional arrangements. Gandhi's civil disobedience movement was a classic blunder that strengthened the hands of Jinnah. In July 1942, he admitted in an interview with an American press representative at Bombay that the defence of motherland was in our own interests, and he argued that Indians should join hands with the British in the persecution of war. British should accept our hands as friends and equal partners to face the peril, and the British Government should provide the share to the Indians in Central and Provincial Governments (Ahmad, 1968).

Jinnah was running the thing with proper planning and Congress was still in a denial mood with the British. They committed a fresh blunder by rejecting the Cripps formula in 1942. Congress was believing in forthcoming Japan's victory and in this perception, they announced the complete independence in Wardha Resolution, 1942. They professed that the British rule should immediately end in India and to attain this prominence Congress would advance in the light of non-violent policy under the leadership of Gandhi (Hodson, 1969).

Jinnah assumed it as the weapon of blackmailing and the declaration of war against the British rule in India. He again reprimanded the British about the intention of the establishment of a Hindu Raj by the Congress. He blamed the Congress would sacrifice all other intentions and Muslims interest in India to establish a majoritarian rule in the country (Trivedi, 2011). As a result of these resolutions, a serious disturbance was followed by the Congress workers, which resulted in chaos and disruption of communication between the war zone of Burma and Delhi (Stephan, 1976). In the response to Congress policies, the British reaction was far tough; the whole leadership of Congress were put in jail till the late summers of 1945. This was a golden opportunity for Jinnah and his followers to rectify the balance of power between the Muslim League and Congress (Wallbank, 1958).

Jinnah attained another practical success when Gandhi expressed his desire to meet him. The main objective of this meeting was to convince Jinnah on the ideals of Gandhi, united India, and the overt objective to resolve the Congress-League rift. After the failure of the Jinnah-Gandhi talks, two tactical points were cashed by Jinnah; recognized as an equal level of Gandhi, the charismatic leader 
of the Hindus, and became successful to acknowledge the demand of Pakistan in Congress-League agenda (Hodson, 1969). Jinnah had already known the fact that Gandhi would never accept his demand of Pakistan and he had no full authorization from Congress to negotiate with him (Prayer, 2012). Apart from that, he believed this meeting would improve his position and the repute of the Muslim League among the Muslims. Jinnah added two more important objectives for this meeting; firstly, he was pushing forward the Pakistan scheme to convey the Congress as a soled message. Secondly, he desired to portray the reality of two-nation theory to the British and he was enthusiastic to gain equal representation for Muslim League. It opened up the way for the British to negotiate with League and when the leading opponent Congress was willing to negotiate, then why the British couldn't (Pandey, 1999).

No doubt, Jinnah had a significantly groomed sense of goal orientation and task management. He rightly attained the place of sole spokesman or sole representative of the Muslims (Casci, 1998). According to his political strategy, it was the right time to project that the creation of a Muslim state only workable resolution to the Hindu-Muslim communal question. After the failure of Jinnah-Gandhi talks, he openly declared, the only solution to Hindu-Muslim differences lay in the partition of India. The division of India into Pakistan and Hindustan would bring a chance for us to trust each other, and provide a respectable assurance to the minorities in both parts (Bolitho, 2006).

After the Second World War, the world was totally changed, and the British had no capacity to rule further in their colonies. Now American pressure was increasing on the British to resolve the problem of its colonies. For this said purpose British sent a Cabinet Mission in 1946, with a constitution structure which offered the eventual assurance of self-government. Before the announcement of the Cabinet Mission plan, Congress-League had divergent strategies. League insisted upon the weak Centre and strong provincial setup. Whereas Congress demanded a strong Centre and a weak provincial system. Jinnah wanted the British to divide and then quit whereas Congress demanded independence only. On 16 May 1946, the Cabinet Mission plan was announced, the British authorities rejected the demand of Pakistan and apart from its Muslim League accepted the Cabinet Mission Plan. The main reason behind this acceptance, there was a grouping of six Muslim provinces in groups B and C (Khaliq-uz-Zaman, 1961). Jinnah as compared to the demand of Pakistan emphasized on the right to secede from the Indian Union (Tinker, 1967). Jinnah didn't concede the essence of Pakistan in this compulsory grouping.

In this plan, the British announced the formulation of an interim setup, truly based on the Indian representatives mainly from Congress and League, until the new constitutional framework was not accomplished. Jinnah was willing to get assurance from the Wavell that the League would be the part of interim setup even if Congress reject it (Prayer, 2012). Wavell gave the assurance to Muslim League on $4^{\text {th }}$ June and Muslim League accepted the plan on $6^{\text {th }}$ June 1946. Jinnah's strategies were frolicking fair left marks not only on Wavell but also upon members of the plan. Before a meeting with Gandhi and Patel, Alexander was in favour to inform Jinnah and he thought that Jinnah played a positive role and Congress remained unpredictable during this whole process (Tinker, 1967).

Finally, after three months, the Cabinet Mission had to leave India without procuring an agreement between Congress and League. Jawaharlal Nehru, the Congress President announced, they are entirely free to determine the situation. They had committed themselves on no single matter to anybody (Wallbank, 1958). It was very surprising for Jinnah, and he reversed his acceptance of the Cabinet Mission Plan. He declared the $16^{\text {th }}$ of August 1946 as the Direct-Action Day. This peaceful procession turned into chaos and a huge riot which resulted in heavy losses.

Wavell and the British were not able to witness a civil war in India, he decided to invite Jinnah for the negotiations. Jinnah accepted his proposal and decided to join the interim government. By accepting participation in the interim government, Jinnah secured the two tactical victories. First, League could nominate a member of the schedule cast in the cabinet, and secondly, the prominent finance ministry was given to Khan Liaquat Ali Khan (Talbot, 1994). Jinnah was fully aware of the fact that remaining outside the interim government would harm the political position of the Muslim League. The British government was unable to break the deadlock between Congress and League. They finally announced to handed over the powers to native Indian political leadership and decided to quit India by June 1948 (Oldenburg, 1985). Lord Mountbatten, the last Governor-General of India, had the responsivity to transfer the power and on $3^{\text {rd }}$ June 1947, he announced the partition of India. This announcement was welcomed by both major parties of India, Congress, and the Muslim League. 
This was the final victory of Jinnah against the Congress to secure a new motherland for the Indian Muslims.

\section{CONCLUSION}

The contemporaries of Jinnah described him as a 'powerful debater and a first-class strategist'. He displayed his charismatic and strategic abilities during the years 1935 to 1947 . This period was full of systematic strategies which he devised in his mind for his success. In 1937, Allama Iqbal suggested him to struggle for a separate Muslim state and he denied it by showing no internet. According to his leadership abilities, the situational factor was not in favour of this demand. At that time, he was seeking sufficient strength and support for League. Jinnah as a cool, calculating strategist and a charismatic leader decided to concentrate on the reorganization of the League, and finally, he transformed it into a powerful organization of the Indian Muslims. After acquiring the mass strength only then he announced his goals. When he announced the demand for a separate state for the Muslims, he had recognized the Muslim League as the sole representative of the Muslims in India. Historians believed that Jinnah, being a great leader, employed master strategies to create a nationstate for the Indian Muslims, Pakistan.

\section{REFERENCES}

Ahmad, J.-u.-D. (1968). Speeches and Writings of Mr. Jinnah Vol. I. Lahore: Sh. Mohammad Ashraf. Bilgrami, A. (1985). Jinnah. Grand Street, 4(3), 191-205. doi:10.2307/25006749

Biswas, S. (2021). Gandhi's Struggle against Caste and Untouchability in South Africa, 1893-1914. South Asian Review, 42(1), 3-17. doi:10.1080/02759527.2020.1765069

Blanchot, M. (2012). Mahatma Gandhi. Journal for Cultural Research, 16(4), 361-365. doi:10.1080/14797585.2011.642107

Bolitho, H. (2006). Jinnah the Creator of Pakistan Karachi: Oxford University Press

Camboni, M. (2004). Networking Women: Subject, Place, Links Europe-America: Towards a Rewriting of Cultural History, 1890-193 9. Macerata: Storia e Leteratura.

Casci, S. (1998). Muslim Self-Determination: Jinnah Congress Confrontation, 1943-44. Il Politico, 63(1 (184)), 67-85.

Corder, C., \& Plaut, M. (2014). Gandhi's Decisive South African 1913 Campaign: A Personal Perspective from the Letters of Betty Molteno. South African Historical Journal, 66(1), 2254. doi:10.1080/02582473.2013.862565

Datta, V. N. (2002). Iqbal, Jinnah and India's Partition: An Intimate Relationship. Economic and Political Weekly, 37(50), 5033-5038.

Hayat, S. (2008). The Charismatic Leader. Karachi: Oxford University Press.

Hobson, P. (2002). Gandhi's Philosophy of Education. Australasian Journal of Philosophy, 80(4), 541-542. doi:10.1093/ajp/80.4.541

Hodson, H. V. (1969). The Great Divide London Hutchinson.

Jalal, A. (1998). Nation, Reason and Religion: Punjab's Role in the Partition of India. Economic and Political Weekly, 33(32), 2183-2190.

Jalal, A. (2010). The Sole Spokesman Lahore: Sang-E-Meel Publication.

Khaliq-uz-Zaman, C. (1961). Pathway to Pakistan Lahore: Longman.

Moore, R. J. (1983). Jinnah and the Pakistan Demand. Modern Asian Studies, 17(4), 529-561.

Nichols, B. (1944). Verdict on India. Bombay: Thacker \& Co.

Oldenburg, P. (1985). "A Place Insufficiently Imagined": Language, Belief, and the Pakistan Crisis of 1971. The Journal of Asian Studies, 44(4), 711-733. doi:10.2307/2056443

Pandey, G. (1999). Can a Muslim Be an Indian? Comparative Studies in Society and History, 41(4), 608-629.

Prayer, M. (2012). Mahatma Gandhi and Nationalist India as Seen by the Catholic Church, 192019481. Journal for Cultural Research, 16(4), 371-392. doi:10.1080/14797585.2012.640861

S.M. Burke, S. A.-D. Q. (2009). Mohammad Ali Jinnah: His Personality and His Politics. Karachi Oxford University Press, .

Sayeed, K. b. (1968). Pakistan the Formative Phase Karachi: Oxford University Press.

Stephan, I. (1976). The Pakistan. London: Oxford University Press. 
Talbot, I. (1994). Planning for Pakistan: The Planning Committee of the All-India Muslim League 1943-46. Modern Asian Studies, 28(4), 875-889.

Tinker, H. (1967). Experiment with Freedom: India and Pakistan 1947. London: Oxford University Press.

Trivedi, H. (2011). Revolutionary Non-Violence. Interventions, 13(4), 521-549. doi:10.1080/1369801X.2011.628114

Wallbank, T. W. (1958). A Short History of India and Pakistan. New York New American Library 